\title{
Justifying Non-Violent Civil Disobedience within the Kenyan Context: A Moral Perspective
}

\author{
Reginald M.J. Oduor \\ Department of Philosophy and Religious Studies
}

University of Nairobi, Kenya

rmjoduor@gmail.com

Thought and Practice: A Journal of the Philosophical Association of Kenya (PAK)

New Series, Vol.3 No.1, June 2011, pp.21-59

thoughtandpractice@gmail.com

http://ajol.info/index.php/tp/index

\begin{abstract}
This paper employs the critical and analytical techniques of philosophical reflection to present a moral justification for the use of non-violent civil disobedience by Kenyan citizens in pursuit of their aspirations. It sets out with a brief review of political disobedience in Kenya from the advent of the British invasion and domination of the country in the late nineteenth century to the present. Next, it examines the nature of non-violent civil disobedience, outlining the views of four of its most influential advocates, namely, Étienne de La Boétie,
\end{abstract}


Henry David Thoreau, Mohandas Karmachand Gandhi and Martin Luther King, Jr. It then offers a moral justification for non-violent civil disobedience by presenting nine arguments in its favour, with special reference to the Kenyan context. Thereafter, it answers six objections to non-violent civil disobedience. The paper concludes that it is high time that Kenyans gave serious consideration to a commitment to non-violent civil disobedience.

Key Words. Civil disobedience, moral justification, violence, Kenya

\section{Introduction}

Since political life is about competing interests, dissent is part and parcel of it. What is more, democracy, as widely understood today, is a system of government in which dissent is an integral part of the political process. Nevertheless, although many regimes claim to be democratic, they ignore, muffle or suppress political dissent. Such intolerance frequently heightens the intensity of the expression of dissent, resulting in political disobedience - instances in which men and women take steps not permitted by an authority to effect changes in the policy, laws, government, or constitution of the state in which they live (Macfarlane 1968, 31, 37).

Like many other governments, the Kenyan government urges citizens to use legally sanctioned means to push for any constitutional, legal or policy changes they may desire. Such means include licensed demonstrations and political rallies, voting in elections, litigation, and participation in formal processes designed to review the constitution or the subordinate laws of the land. However, the Kenyan government often frustrates citizens' bids to use these channels. For example, it frequently declines to grant licenses for demonstrations and political rallies organised by perceived opponents, and goes ahead to violently disperse them. This was the case during the clamour for the restoration of multi-party politics in the 1980s and early 1990s, after the 2005 referendum on the then proposed new constitution ("the Wako Draft"), and in the aftermath of the disputed 2007 general elections, among others. 
Even after the promulgation of the new Kenyan constitution in August 2010, a document whose bill of rights is significantly enhanced, the government continues to deny citizens licenses for demonstrations and political rallies. Consequently, dissatisfied citizens often resort to political disobedience in the form of unlicensed demonstrations or political rallies, which begin peacefully, but turn violent when the crowds attempt to resist the state's violent action against them. As a result, many Kenyans now have the false impression that civil disobedience is necessarily violent in nature.

In view of the foregoing observations, this paper employs the critical and analytical techniques of philosophical reflection to present a moral justification for the use of non-violent civil disobedience by Kenyan citizens in pursuit of their aspirations. To justify an action is to show that it is rational (Gert 1969, 618). In his seminal work, Rethinking Criminal Law (2000), George P. Fletcher made a distinction between justification and excuse. He noted that claims of justification concede that the definition of the offense is satisfied, but challenge whether the act is wrongful; on the other hand, claims of excuse concede that the act is wrongful, but seek to avoid the attribution of the act to the actor. In short, a justification speaks to the rightness of the act; an excuse, to whether or not the actor is accountable for a concededly wrongful act (Fletcher 2000, 759).

In this paper, the focus on the moral justification for non-violent civil disobedience is based on the fact that political philosophy seeks to apply moral concepts and norms to the evaluation of humankind's collective existence. Indeed, political philosophers have presupposed moral values such as freedom, responsibility and justice. Thus Plato (1945) advocated justice as the aim of society; Aristotle (2000) prescribed society's role as that of facilitating the cultivation of virtue in the individual; John Stuart Mill's moral and political theories were linked by his insistence that both morality and politics be governed by the principle of utility (Mill 1972; 1999); John Rawls (1971) considered justice to be pivotal to the creation of a sustainable democratic order. 
The paper sets out with a brief review of political disobedience in Kenya from the advent of the British invasion and domination of the country in the late nineteenth century to the present. Next, it examines the nature of non-violent civil disobedience, outlining the views of four of its most influential advocates, namely, Étienne de La Boétie, Henry David Thoreau, Mohandas Karmachand Gandhi and Martin Luther King, Jr. It then offers a moral justification for non-violent civil disobedience by presenting nine arguments in its favour, with special reference to the Kenyan context. Thereafter, it answers six objections to non-violent civil disobedience. It is crucial to bear in mind that the present paper does not call upon Kenyans to engage in non-violent civil disobedience. Instead, it contends that in the event that Kenyans feel compelled to engage in civil disobedience, they ought to choose the non-violent rather than the violent option.

\section{Political Disobedience in Kenya: The Seesaw of Violent and Non-violent Expression}

In Kenya, widespread political disobedience began with the advent of the British invasion and subjugation of the country, which commenced with the formal inauguration of the Imperial British East Africa Company rule in 1888, but more officially with the declaration of British East African Protectorate on 1st July, 1895 (Kihoro 2005, 8). An 1886 Anglo-German agreement had delineated the sovereignty of the Sultan of Zanzibar from the country's coastline to ten miles into the interior (Brennan 2008, 838). In 1895, the Sultan of Zanzibar leased the administration of the strip to the British. These events set in motion the process of placing different ethnic communities with their diverse systems of government within one large and new area of central administration (Olumwullah 1990, 88; Jonyo 2002,90$)$. The territory beyond the ten-mile coastal strip was declared to be "Kenya Colony" in 1920 (Omolo 2002, 213). Thus while the ten-mile coastal strip continued to be referred to as a Protectorate, the rest of the country was henceforth referred to as the Kenya Colony (Brennan 2008, 831). Nevertheless, the British administered the Protectorate and the Colony as a two-in-one unit out of expediency (Hassan 2002). 
It is evident that the term "colonialism" is a euphemism for robbery with violence at an inter-state or inter-cultural level. Indeed, the American Heritage Dictionary defines "colonialism" as "A policy by which a nation maintains or extends its control over foreign dependencies." Such a venture entails the use of violence and subterfuge, for cultural groups typically resist foreign subjugation. Indeed, Kihoro (2005) has chronicled the violent British incursions into the lands of various ethnic communities now subsumed under Kenya, including those of the Giryama at the coast, the Kamba and the Embu in the east, the Kikuyu in central Kenya, the Nandi and the Maasai in the Rift Valley, and the Gusii and Tachoni in the west. Due to the plan of this paper, it is not possible to present the detailed history of the liberation struggles of the various communities. Instead, we shall only highlight a few incidents of violent and non-violent resistance over the past century or so.

In the early years of the British invasion of present-day Kenya, the various peoples often engaged in violent resistance against them. Kihoro (2005) demonstrates that the British robbed various communities of their land, foodstuff, livestock, money and political sovereignty. These peoples struggled to free themselves from British subjugation, and the British responded with imprisonments, deportations and murders. For example, in 1892, the British buried Waiyaki wa Hinga alive. He was a Kikuyu leader in Dagoretti, who had mobilized his people to violently resist the robbery of their food supplies by officials of the Imperial British East Africa Company (Kihoro 2005, 5-7). Similarly, in 1895, the British violently suppressed the resistance of the Tachoni of Western Kenya, and dispossessed them of their livestock (Kihoro 2005, 10). Thus with regard to the advent of the British invasion and domination of the territory now called Kenya, John Lonsdale $(1989,6)$ wrote that "The British employed violence on a locally unprecedented scale, and with unprecedented singleness of mind".

One of the most well known instances of non-violent resistance to British hegemony in Kenya was that organised by Harry Thuku, who founded the East African Association (EAA) in 1922 (by changing the name of the Young Kikuyu Association). Thuku held meetings and traveled far and wide in an effort to wake up the people to the injustices committed on them by the foreign invaders. The 
new movement protested the stealing of African lands, reduction of wages paid to Africans in the post-First World War depression, high Poll Tax demands and poor working conditions on the settler estates (Kihoro 2005, 25). Thuku forged a working relationship with the EAA, the Young Kavirondo Association (YKA) and the Indian community. There were plans for him to visit India to learn some organizational skills from the Indian Congress Party. Besides, he was in communication not only with the "Young Baganda" in Uganda, but also with the Tuskegee Institute in Alabama, U.S.A (Kihoro 2005, 25-28).

The British considered Thuku to be very dangerous, especially when the masses started to look up to him for leadership (Kihoro 2005, 25). Consequently, they arrested him in March 1922. As a result, large crowds assembled at the Kingsway Police Station, now Central Police Station, to demand for his release. The British security forces opened fire on the crowds, resulting in the death of Seventeen men and five women (Kihoro 2005, 27). Thuku and two of his comrades, Waiganjo wa Ndotono and George Muge Kanyi, were exiled, without trial, to Kismayu, then part of Kenya but now in Somalia (Kihoro 2005, 28).

Another non-violent protest against British domination and exploitation came from the Akamba of Machakos, who, in 1938, resisted the invaders' demand that they cull their livestock. This protest was led by Samuel Muindi Mbingu, the President of the Akamba Members Association (AMA). Muindi Mbingu led Over three thousand men, women and children in a 70 Kilometre march to Nairobi to present their grievances to the Governor, but the Governor declined to meet them there, despite their three-week stay in Nairobi. Eventually, through subterfuge, the British arrested Mbingu and deported him to Lamu (Kihoro 2005, 35).

The British were imposing the policy of destocking on the Akamba of Machakos because, purportedly, the 1929 Agricultural Commission had recommended compulsory reduction of livestock in the Kamba Reserve on the grounds that the reserve had excess livestock. Nevertheless, it was widely known that behind the policy was the fact that Liebigs Co. Ltd., a meat processing and canning factory, had commenced operation in 1936 in Athi River at a time when there were high 
prices for cattle and low prices for beef world wide. In the midst of this contradictory market situation, Liebigs was on the verge of closing down by 1938 (Kihoro 2005, 33).

The best known violent resistance against foreign domination in Kenya is the Mau Mau Uprising in the 1950s. According to John Lonsdale (1990), the Mau Mau secret society first emerged in 1948 among Kikuyu labour tenants on European settler farms. The movement was banned in 1950. In 1952 violence flared on the farms, in the slums of Nairobi and in the Kikuyu reserve. A new governor, Evelyn Baring, declared an emergency in October 1952. However, the British did not win the military initiative until early 1954, by which time the British forces in Kenya were a full infantry division, and the police had multiplied threefold. The British army left in 1956, after a four-year war (Lonsdale 1990).

However, there has been an intense debate among scholars concerning the real nature of what came to be referred to by the colonialists as "the Mau Mau rebellion", and by many African historians as "The Mau Mau Uprising". ${ }^{1}$ Thus while Norman (1954) referred to the "Mau Mau" as a "crime" and to their activities as entailing a "terrorist war", George Padmore (1953) saw the violent uprising as a liberation struggle of an oppressed people. Similarly, Odinga (1967), Kinyatti (2000) and Kihoro (2005 are all emphatic that the Mau Mau movement was formed by the Africans to liberate themselves from foreign oppression and exploitation. Whatever view one takes of the Mau Mau, it is difficult to gainsay the fact that the uprising was at least in part violent resistance against foreign invasion and domination. This is indicated by the fact that its armed wing was called the Kenya Land Freedom Army (Kinyatti 2000, 22).

Just before Kenya attained political independence in 1963, there was another bout of violent civil disobedience, only that this time the conflict was between indigenous Africans. The rivalry between the two dominant political parties, the Kenya African National Union (KANU) and the Kenya African Democratic Union (KADU) intensified, mainly around the issue of the distribution of land.

\footnotetext{
${ }^{1}$ See Berman (1991) for an enlightening outline of the debate.
} 
KANU advocated for a strong central government, while KADU canvassed for a federal government (Ndegwa 1997, 606). Emotions were worked up by KADU's Masinde Muliro, who declared that if KADU's regional plan was not accepted, KADU's leaders had a secret master plan. William Murgor, then Parliamentary Secretary for Defence and Internal Security in the transitional government, invited his fellow Kalenjins to sharpen their spears and wait for the sound of his whistle for the beginning of the war to drive non-Kalenjins out of the Rift Valley. Daniel arap Moi, then Chairman of KADU, vowed to shed his blood to ensure that regionalism was written in the independence constitution (Atieno-Odhiambo 2002, 239).

It was therefore not surprising that from 1961, inter-ethnic clashes swept through the Rift Valley Province. The Kikuyu, Luhya and other ethnic groups, who had lived in the area for years, were labeled foreigners, their houses were burnt, and the majority of them were displaced from their homes (Ajulu 2002, 259). Since these violent acts were evidently political and at the same time beyond the confines of the law, they constituted violent civil disobedience.

At the attainment of Kenya's political independence in 1963, Jomo Kenyatta ascended to leadership, first as Prime Minister, then as President. The change from Prime Minister to President was crucial to the process of increasing Kenyatta's unchecked power. As Prime Minister, Kenyatta was directly answerable to Parliament, and it is this accountability that he sought to put aside through a series of constitutional amendments. First, Kenyatta's KANU government initiated a series of constitutional amendments that concentrated power in the hands of the central government at the expense of the eight federal governments. These amendments produced a strong provincial administration, which became an instrument of central control. Second, under Kenyatta, KANU initiated amendments which produced a hybrid constitution, in which the inherited parliamentary system of governance was replaced by a strong executive presidency without the checks and balances expected from separation of powers (Badejo 2006, 254-255). 
In the late 1960s, violent civil disobedience was to be seen in the rivalry between Jomo Kenyatta's party, KANU, and Oginga Odinga's Kenya People's Union (KPU). During Kenyatta's visit to Kisumu in October 1969, just three months after the assassination of Thomas Joseph Mboya, the charismatic Minister for Planning, a large crowd of Luos reportedly threatened Kenyatta's security, and was fired on by Kenyatta's guards in what later came to be known as the "Kisumu massacre", resulting in the death of Forty-three people. In an explanatory statement, the government accused Odinga's Kenya People's Union (KPU) of being subversive, intentionally stirring up inter-ethnic strife, and of accepting foreign money to promote anti-national activities. Soon after this incident, the Attorney-General Charles Njonjo banned "Kenya Peoples Union and all its branches and sub-branches" under Legal Notice No.239 of 30th October 1969, and Kenya became a de facto one party state. Several KPU leaders and MPs were also immediately apprehended and detained (Kihoro 2005, 157).

Kenyatta's autocracy continued to stifle political dissent until his death in 1978. Nevertheless, Kenyans continued to engage in various forms of political disobedience. For example, in 1975, there were student demonstrations to protest the assassination of the popular Member of Parliament for Nyandarwa North, Josiah Mwangi Kariuki. Academics also wrote fictional and non-fictional pieces protesting rampant corruption and political intolerance, and had to endure various forms of reprisals for their actions.

The transition from the Kenyatta to the Moi autocracy in 1978 was free from overt controversy, mainly because the Kenyatta regime had smothered genuine competitive politics for a decade and a half. However, in the Moi era, there were numerous instances of both non-violent and violent civil disobedience. Furthermore, the year 1990 was critical in the construction of alliances that brought the debate about political pluralism to the streets of Nairobi for the first time since the Odinga-led opposition Kenya Peoples Union (KPU) was banned by the Kenyatta regime in 1969. A number of forces were marshalled against Moi's single-party regime. Among these were the original radical tradition of dissent sustained by Oginga Odinga for three decades, opposition from several religious leaders, a tradition of protest sustained by groups of intellectuals and students at 
university campuses since the 1960s, a group of reformist constitutional lawyers, and Western bilateral and multilateral financiers (Atieno-Odhiambo 2002, 226; Badejo 2006, 156-176).

One of the instances of violent civil disobedience during Moi's reign involved the agitation for the restoration of multiparty politics. On $4^{\text {th }}$ July, 1990, three days before a proposed rally in Nairobi to pressure the Moi regime to allow for multiparty politics, police arrested and detained Charles Rubia, Kenneth Matiba, several lawyers and other political leaders. The crackdown on these opposition figures provoked large-scale violence all over the country. The riots began on $7^{\text {th }}$ July 1990, and lasted about five days. The centers of violence were in and around Nairobi, and in the main towns of the Central Province such as Nyeri, Murang'a and Thika. Kisumu was a center of violence in Nyanza. Students from all university campuses also demonstrated in favour of a multi-party system. According to government sources, twenty-seven people were killed during the Saba Saba events (as they were later known). However, unofficial estimates claim that there were over one hundred fatalities and hundreds of injured (not to mention the burned houses and stolen property) (Sabar-Friedman 1995, 114-115).

On the other hand, the non-violent strategy of the Release Political Prisoners (RPP) lobby in the early 1990s also met with force from the Moi regime. In support of the demand for the release of political prisoners, a mothers' hunger strike was launched on $28^{\text {th }}$ February, 1992. The mothers, relatives and friends of political prisoners delivered a petition to the Attorney General demanding their release. Fourteen women then began their hunger strike in Uhuru Park in Nairobi to await the government's response. On the fourth day, a peaceful demonstration in solidarity with the women was attacked by heavily armed police, resulting in the injuring of scores of people. The following day all the women were detained, as were their supporters in the RPP who were present. Anti-government riots erupted in Nairobi, but were violently put down by police. Following their release, the women regrouped at the All Saints Cathedral. On 7th March 1992, a group of women began another hunger strike in Mombasa. They too were detained but 
released after two days (Dixon 1992). The Moi regime was eventually compelled to release all political prisoners.

Thus far in the history of independent Kenya, the grizzly effect of the use of violence for political ends was picturesquely illustrated by the aftermath of the disputed 2007 general elections (CIPEV 2008, p.vii). Despite the loud protests concerning the rampant election anomalies, Mwai Kibaki of the Party of National Unity (PNU) was declared the winner over Raila Odinga of the Orange Democratic Party (ODM) by a lead of 231,728 votes in the late afternoon of 30 th December 2007, and then hurriedly sworn in (IREC 2008, 2). The swearing in was conducted at twilight in a heavily guarded statehouse function, with Kibaki surrounded only by his closest associates. This was in sharp contrast to his first swearing in on 30th December 2002, which took place in broad daylight at Uhuru Park, with a large, enthusiastic crowd in attendance (Wrong 2009, 1 ff.).

Within minutes of the announcement of Kibaki's contested victory, the multiethnic settlements of Nairobi, Mombasa, Kisumu, Eldoret and Kakamega erupted into violence. Luo and Luhya ODM supporters armed with metal bars, machetes and clubs vented their frustration on local Kikuyu and members of the smaller pro-PNU Meru, Embu and Kisii ethnic groups, setting fire to their homes and shops (Wrong 2009, 307). The worst unrest was around the Northern Rift Valley town of Eldoret, where Kalenjins mobilised against Kikuyus, driving them away and burning their property. There was also serious violence in the Southern Rift Valley, with Kalenjin attacks on Kisii communities over land ownership issues, and in Western Kenya, particularly in Kisumu, where Luo ODM supporters were shot by the police. In the Rift Valley towns of Naivasha, Molo and Nakuru, the Mungiki, a Kikuyu outlawed militia, attacked ODM supporters. Families from the minority Ogiek hunter-gatherer community close to Nakuru had their houses and other property destroyed by Kikuyu villagers. By the time the power-sharing deal was struck on 28th February 2008, bringing together the ODM and the PNU, approximately 1,500 Kenyans had been killed, over 400,000 displaced, and an unknown number of women had been raped (CIPEV 2008; KNCHR 2008, 9; Matheson 2008). 
Thus it is evident that since the advent of the British invasion and domination in the late nineteenth century, Kenyans have engaged in both violent and non-violent civil disobedience in pursuit of their aspirations. Even more significant is the fact that in post-independence Kenya, political disobedience has continued to seesaw between violent and non-violent forms. Despite the fact that post-independence Kenya has not sunk into statelessness as Somalia did in the early 1990s or into allout genocide as occurred in Rwanda in 1994, she has had considerable political turmoil, whose climax was the crisis after the disputed 2007 general elections. While the independence constitution and the constitution promulgated in August 2010 both have provisions for civil liberties, the three regimes that have ruled the country since independence (Kenyatta, Moi and Kibaki) have repeatedly sought to curtail the enjoyment of those rights, resulting in various forms of violent and non-violent civil disobedience. As such, there is an urgent need for Kenyan philosophers to reflect on the moral implications of the two kinds of civil disobedience, with a view to assisting their compatriots to make informed choices. As a contribution to such reflection, this paper is devoted to a moral justification for non-violent civil disobedience. In preparation for this task, it is necessary to examine at some depth the nature of non-violent civil disobedience.

\section{The Nature of Non-violent Civil Disobedience}

In the introduction to this paper, we noted that political disobedience entails instances in which men and women take steps not permitted by authority to effect changes in the policy, laws, government, or constitution of the state in which they live (Macfarlane 1968, 31, 37). It is important to distinguish between ordinary acts of law breaking and acts of political disobedience. In general, those who deliberately break the law to secure changes in the policy, laws, government, or constitution of the state do not hope for any narrow personal gain. Instead, they seek either the good of the whole society, or the good of the group with which they identify. Actions of this nature are easily distinguishable from those of the ordinary criminal, whose objection is not to the law he or she breaks, but rather to the penalties applied if he or she is caught (Macfarlane 1968, 30). 
Paullin (1944) structured his discussion of political disobedience on the basis of six types resulting from a continuum, at one end of which he placed violence coupled with hatred, and at the other, dependence only upon the application of positive love and good will. In the intermediate positions there are possibilities such as the following:

(1) Violence without hatred.

(2) Non-violence practiced by necessity rather than because of principle.

(3) Non-violent coercion.

(4) Satyagraha ${ }^{2}$ and non-violent direct action.

(5) Non-resistance.

However, Brownlee (2007) has correctly observed that the various points of contact and overlap amongst different types of political protest suggest that there is no one-dimensional continuum from weak to strong dissent. Instead, there is more plausibility in the idea of a multi-dimensional continuum of protest, which recognises the complexities in such critical points of contrast as legality, violence, harm, communication, motivation and persuasiveness.

Non-violent civil disobedience refers to actions taken by a disgruntled group to challenge a law or a social order without any use of physical force. Tactics of nonviolent civil disobedience may include strikes, boycotts, mass demonstrations, refusal to pay taxes, destruction of symbols of government authority (such as official identification cards), refusal to obey official orders (such as curfew restrictions), and the creation of alternative institutions for political legitimacy and social organisation (Zunes 1997). Nevertheless, it should be noted at the outset that some of those who engage in non-violent action do not have an ethical commitment to it, but simply choose it for pragmatic purposes. Thus many socalled non-violent uprisings have not been exclusively non-violent. Indeed, some have included riots, sabotage, and the murder of collaborators (Zunes 1997). This expedient use of non-violent action can partly be accounted for by the fact that a

\footnotetext{
2 The word satyagraha was coined by Gandhi in South Africa to distinguish the non-violent resistance of the Indians of South Africa from the contemporary 'passive resistance' of the suffragettes and others (see Gandhi 1961, 3).
} 
similarity that liberation movements share across the world is that they must develop a collective action strategy that will generate leverage, enabling them to engage in power struggles with opponents who have superior military might (Morris 1999, 529). In the light of this reality, non-violent civil disobedience is a tactic well suited to struggles in which a minority group lacks access to major sources of power within a society (Zanden 1963, 544).

For historical reasons, non-violent resistance is often so associated with civil disobedience that "civil disobedience" is frequently understood to refer to "nonviolent civil disobedience". The term "civil disobedience" was coined by Henry David Thoreau in his essay under the same title (Thoreau 1848). He used the phrase to describe his refusal to pay the state poll tax imposed by the American government to prosecute a war in Mexico and to enforce the Fugitive Slave Law. On the most widely accepted account of civil disobedience, famously defended by John Rawls in his seminal work, A Theory of Justice (1971), it is a public, nonviolent, conscientious yet political act contrary to law, usually done with the aim of bringing about a change in the law or policies of the government. By acting in this way one addresses the sense of justice of the majority of the community, and declares that in one's considered opinion the principles of social cooperation among free and equal persons are not being respected (Rawls 1971, 364). Nevertheless, in view of the fact that other writers consider the use of violence to be a type of civil disobedience, we shall use the term "non-violent civil disobedience", thereby eliminating the possibility of ambiguity.

The purpose of non-violent civil disobedience can be to publicise an unjust law or a just cause, to appeal to the conscience of the public, to force negotiation with recalcitrant officials, to get into court where one can challenge the constitutionality of a law, to exculpate oneself, or to put an end to one's personal complicity in the injustice which flows from obedience to unjust law - or some combination of these (Suber 1999).

One of the earliest articulations of non-violent civil disobedience is that by Plato in the Apology and the Crito (Plato 2009a, 2009b). In the Apology, Plato presents 
Socrates as declaring that while he is committed to obeying the dictates of the state, he is obliged to disobey them whenever they conflict with the express will of the gods, even if the state threatens to put him to death for doing so. Socrates goes on to assert that if the Athenians were to sentence him to death, they would thereby injure themselves more than him. This position is pivotal to the doctrine of non-violent civil disobedience, which seeks to appeal to the conscience of the oppressor through the suffering he or she inflicts on the oppressed.

In the Crito, Plato presents Socrates advancing three arguments in support of the view that it is virtuous to submit to the decision of the state to sentence him (Socrates) to death, and therefore that it is vicious for him to escape from prison:

- We ought not to harm anyone, yet escaping from prison would harm the state.

- We ought to keep our promises, yet escaping from prison would be tantamount to breaking the promise of loyalty to the state.

- We ought to obey and respect our parents and teachers, yet escaping from prison would be tantamount to disobedience and disrespect to the state which enjoys the status of a parent or teacher.

Plato's Socrates hence provided the precedent for a tradition of dissent that aims at resisting a specific authority, law, or policy considered unjust, while at the same time recognising the rulemaking prerogative of the existing political system as legitimate and generally binding (Bleiker 2002, 37).

Since Plato, the doctrine of non-violent civil disobedience has undergone significant change, especially in terms of the strategies for its implementation. For while Plato's Socrates did not go out to challenge the status quo through openly confrontational means, this very strategy is at the heart of contemporary nonviolent civil disobedience. Thus as presently understood, non-violent civil disobedience involves suddenly thrusting the initiative to a political authority for a conflict with unarmed citizens that it cannot avoid, and which will also have the inevitable consequence of alienating it from a portion of the on-looking subjects/citizens. Furthermore, because the resister is unarmed and "suffers" 
imprisonment, being beaten, etc., the onus of responsibility for all the suffering falls squarely on the authority (Tinker 1971, 777-778).

The basic assumption of non-violent civil disobedience is that governments are ultimately dependent on the fearful obedience and compliance of their subjects. This was succinctly stated by the sixteenth century French jurist and political philosopher, Étienne de La Boétie (1530- 1563), who wrote his seminal essay, Discours de la Servitude Volontaire ("The Discourse of Voluntary Servitude") in 1552-53 (Rothbard 2002, 9). In his abstract, universal reasoning, his development of a true political philosophy, and his frequent references to classical antiquity, La Boétie followed the method of Renaissance writers, notably Niccolo Machiavelli (see Machiavelli 1998). However, whereas Machiavelli attempted to instruct the Prince on effective means of cementing his rule, La Boétie was dedicated to identifying ways to overthrow the prince, and thereby to secure the liberty of the individual (Rothbard 2002, 12).

For La Boétie, all that the oppressed masses need to do in order to overthrow the tyrant is to withdraw their co-operation from him:

He who ... domineers over you has only two eyes, only two hands, only one body, no more than is possessed by the least man among the infinite numbers dwelling in your cities; he has indeed nothing more than the power that you confer upon him to destroy you. Where has he acquired enough eyes to spy upon you, if you do not provide them yourselves? How can he have so many arms to beat you with, if he does not borrow them from you? The feet that trample down your cities, where does he get them if they are not your own? How does he have any power over you except through you? How would he dare assail you if he had no cooperation from you? What could he do to you if you yourselves did not connive with the thief who plunders you, if you were not accomplices of the murderer who kills you, if you were not traitors to yourselves? .... Resolve to serve no more, and you are at once freed. I do not ask that you place hands upon the tyrant to topple him over, but simply that you support him no longer; then you will behold him, like a great Colossus whose pedestal has been pulled away, fall of his own weight and break into pieces (La Boétie 2002, 4849).

Rothbard $(2002,18)$ observes that it was a medieval tradition to justify tyrannicide of unjust rulers who break the divine law, but La Boétie's doctrine, though nonviolent, was in the deepest sense far more radical. For, continues Rothbard, while 
the assassination of a tyrant is simply an isolated individual act within an existing political system, mass non-violent civil disobedience is far more revolutionary in launching a transformation of the system itself. Hence La Boétie was the first theorist of the strategy of mass, non-violent civil disobedience of State edicts and exactions (Rothbard 2002, 37).

David Hume independently discovered the principle of the goodwill of the populace as the ground of government two centuries after La Boétie, and stated it as follows:

Nothing is more surprising to those who consider human affairs with a philosophical eye, than to see the easiness with which the many are governed by the few; and the implicit submission, with which men resign their own sentiments and passions to those of their rulers. When we enquire by what means this wonder is effected, we shall find, that, as Force is always on the side of the governed, the governors have nothing to support them but opinion. It is, therefore, on opinion only that government is founded; and this maxim extends to the most despotic and most military governments, as well as to the most free and most popular (Hume 1870, 23).

Among the most enthusiastic advocates of non-violent civil disobedience have been the anarchist thinkers, who simply extend both La Boétie's analysis and his conclusion from tyrannical rule to all governmental rule whatsoever. Prominent among the anarchist advocates of non-violent civil disobedience have been the 19th century thinkers Henry David Thoreau and Leo Tolstoy. Tolstoy, indeed, in setting forth his doctrine of non-violent anarchism, used a lengthy passage from La Boétie's Discourse as the focal point for the development of his argument (Tolstoy 1948, 42-45).

While the thoughts of La Boétie and Hume on non-violence were purely theoretical, the nineteenth century American thinker, Henry David Thoreau (18171862), took some non-violent action in an attempt to challenge the authority of the state. Because he detested slavery and because tax revenues contributed to the support of it, Thoreau refused to pay the poll tax - a capital tax levied equally on all adults within a community. Consequently, in July 1846, he was arrested and jailed. He was supposed to remain in jail until a fine was paid, which he also declined to pay. However, without his knowledge or consent, relatives settled the 
"debt", and a disgruntled Thoreau was released after only one night (McElroy 2005). The incarceration was brief, but it has had enduring effects, as it prompted Thoreau to write his seminal essay, "Civil Disobedience" (1848), which, as we shall see in subsequent paragraphs, had a profound influence on the thinking of Mohandas K. ("Mahatma”) Gandhi and Martin Luther King, Jr.

Thoreau shared with La Boétie and Hume the view that states continue to exist because of the acquiescence of the citizenry:

Those who, while they disapprove of the character and measures of a government, yield to it their allegiance and support are undoubtedly its most conscientious supporters, and so frequently the most serious obstacles to reform. Some are petitioning the State to dissolve the Union, to disregard the requisitions of the President. Why do they not dissolve it themselves - the union between themselves and the State - and refuse to pay their quota into its treasury? Do not they stand in the same relation to the State, that the State does to the Union? And have not the same reasons prevented the State from resisting the Union, which have prevented them from resisting the State? (Thoreau 1848, Part 2 Par.1).

Nevertheless, as Rosenwald (n.d.) has correctly noted, although proponents of non-violent action often cite Thoreau's "Civil Disobedience" in support of their strategy, non-violence is not a first principle for Thoreau; instead, it is at most a practical preference. Indeed, as Rosenwald (n.d.) further points out, Thoreau criticises the Mexican War not as a war, but as an unjust war; he criticises not prisons, but unjust imprisonments. Moreover, after the passage of the Fugitive Slave Law in 1850, and still more after John Brown's raid, Thoreau defended violent actions on the same grounds as those on which he had defended nonviolent action in "Civil Disobedience" - because, by that time, circumstances had changed, and the actions he found himself called to defend were violent (see Thoreau 1859).

One of the best known organisers of non-violent civil disobedience is the Indian nationalist, Mohandas Karmachand Gandhi, commonly referred to as "Mahatma (“Great Soul") Gandhi" (1869- 1948). As a young lawyer in South Africa protesting the government's treatment of immigrant Indian workers, Gandhi was deeply impressed by Thoreau's essay on civil disobedience. Years later, he thanked the American people for Thoreau as follows: 
"You have given me a teacher in Thoreau, who furnished me through his essay on the 'Duty of Civil Disobedience' scientific confirmation of what I was doing in South Africa" (cited in McElroy 2005).

Gandhi called his overall method of non-violent action Satyagraha. According to Kumarappa (1961, p.iii), Satyagraha can be traced essentially to the Gita ideal of the karmayogin ("the path of selfless and disinterested action"), to Jesus' "Sermon on the Mount", and to the writings of Henry David Thoreau, John Ruskin, and, more especially, Leo Tolstoy; but Kumarappa asserts that Gandhi's practical application of Satyagraha in the social and political spheres was entirely his own. Gandhi himself explained the meaning of Satyagraha as follows:

Satyagraha is literally holding on to Truth and it means, therefore, Truthforce. Truth is soul or spirit. It is, therefore, known as soul-force. .... The word was coined in South Africa to distinguish the non-violent resistance of the Indians of South Africa from the contemporary 'passive resistance' of the suffragettes and others (Gandhi 1961, 3).

Gandhi was at pains to make a sharp distinction between "passive resistance" and Satyagraha. The main difference, according to him, is that passive resistance is not committed to love, but is rather an expedient strategy that can be easily abandoned whenever it was convenient to use violence. On the other hand, Satyagraha is committed to non-violence, considering itself to be the very opposite of violent resistance (Gandhi 1961, 6; Gandhi 2003, 74-75). He believed in confronting his opponents aggressively, in such a way that they could not avoid dealing with him. The difference was that the non-violent activist, while willing to die, was never willing to kill (Shepard 2002). In support of non-violent action, Gandhi argued that if the world were to pursue violence to its ultimate conclusion, the human race would have become extinct long ago (Gandhi 1961, 15-16, 387).

Gandhi practiced two types of Satyagraha in his mass campaigns. The first was civil disobedience, which entailed breaking a law and courting arrest. The second was non-co-operation, that is, refusing to submit to the injustice being fought. It took such forms as strikes, economic boycotts and tax refusals (Shepard 2002). Satyagraha, as developed by Gandhi, became unique among the existing types of generic non-violence by being a matter of principle, including a program for 
social reconstruction and an active individual and group method of effecting socio-political transformation (Sharp 1959, 60).

Gandhi's work greatly influenced the thinking of the African-American Civil Rights leader, Martin Luther King, Jr. (1929- 1968). In contemporary political thought, the term 'civil rights' is indissolubly linked to the struggle for equality of African-Americans during the 1950s and 1960s, whose aim was to secure the status of equal citizenship between African and European Americans (Altman 2007). After slavery was abolished, the US federal Constitution was amended to secure basic rights for African-Americans. In 1877, however, the federal government moved to frustrate efforts to enforce those rights. As a result, state constitutions and laws were modified to exclude African-Americans from the political process.

Consequently, by 1910, the system of legalised segregation and disenfranchisement was fully in place in every state of the former Confederacy (Lyons 1998, 38; Davis n.d.). It is those discriminatory pieces of legislation and court rulings that are collectively referred to as "Jim Crow laws". The disenfranchisement of African-Americans in the South barred them from participating in the political process. They were also kept at the bottom of the economic order, because they lacked even minimal control over land and capital (Morris 1999, 518). Furthermore, segregation and disenfranchisement laws were often supported by ritualised mob violence ("lynchings") against southern African-Americans (Davis n.d.).

It was during the early to mid 1960s that the modern civil rights movement became the organised force that would topple Jim Crow. In this period highly public demonstrations occurred throughout the South, and came to be increasingly strengthened by Northern demonstrations organised in their support (Morris 1999, 525-526). The intensity and visibility of demonstrations caused the Kennedy Administration and the Congress to seek measures that would end demonstrations and restore social order. The Birmingham, Alabama confrontation in 1963 and the 
Selma, Alabama confrontation in 1965 generated the leverage that led to the overthrow of the formal Jim Crow order (Morris 1999, 526-527).

Martin Luther King, Jr. catapulted to fame when he came to the assistance of Rosa Parks, the Montgomery, Alabama African-American seamstress who, on 1st December, 1955, was arrested for refusing to give up her seat on a segregated Montgomery bus to a European-American passenger (Sylvester 1998). Garrow $(1991,86)$ laments that King, Jr.'s plagiarism in his graduate school term papers and doctoral dissertation is fast being pushed to the periphery. Nevertheless, our concern here is not to conduct a forensic investigation into the originality of King, Jr.'s ideas, but rather a philosophical reflection on non-violent civil disobedience. Consequently, we shall put the claims of plagiarism aside, and focus on King, Jr.'s views on non-violence, without seeking to determine how original they were. Indeed, King, Jr. himself was emphatic that he was not the founder of non-violent civil disobedience among African-Americans; rather, he merely served as their spokesman (King, Jr. 1964a, 83).

Like Gandhi, King, Jr. states that his adoption of non-violent civil disobedience was inspired by Thoreau's "Civil Disobedience" (King, Jr. 1964a, 73). Nevertheless, he attributes the details of his strategy to the work of Mohandas K. Gandhi (King, Jr. 1964a, 78). He notes the following concerning Gandhi's influence on him:

It was in this Gandhian emphasis on love and nonviolence that I discovered the method for social reform that I had been seeking for so many months. The intellectual and moral satisfaction that I failed to gain from the utilitarianism of Bentham and Mill, the revolutionary methods of Marx and Lenin, the social-contracts theory of Hobbes, the "back to nature" optimism of Rousseau, and the superman philosophy of Nietzsche I found in the non-violent resistance philosophy of Gandhi. I came to feel that this was the only morally and practically sound method open to oppressed people in their struggle for freedom (King, Jr. 1964a, 79).

In line with Gandhian thinking, King, Jr. (1963b, 2) was of the view that the purpose of direct mass action is to attain a situation in which the opponent is willing to negotiate. King, Jr. (1964a, 83-88) outlines several basic aspects of the doctrine of non-violence as follows: 
- It is not for cowards, but is actually a method of resistance.

- It seeks to win the friendship and understanding of the opponent.

- It attacks forces of evil, rather than persons who happen to be doing the evil.

- It is willing to accept suffering without retaliation.

- It avoids not only external physical violence, but also internal violence of spirit.

- It is based on the conviction that the universe is on the side of justice.

\section{A Moral Justification for Non-violent Civil Disobedience in the Kenyan Context}

In moral philosophy, the debate between deontologists (advocates of duty for duty's sake without any consideration of consequences) and teleologists (advocates of actions that produce desirable consequences) is a drawn out one which this paper cannot purport to resolve. Suffice it to observe that on the one hand, while deontology correctly emphasises the need for conscientiousness by insisting on the sense of duty for duty's sake without consideration of consequences, it thereby detaches morality from the rest of life, and so fails to acknowledge that the purpose of morality is to promote the welfare of humanity. On the other hand, while teleology correctly emphasises the need to act in order to promote human welfare, denying the place of commitment to duty without regard for consequences, it thereby reduces morality to mere prudence. Thus deontology and teleology each gives a useful but partial account of morality, so that a more comprehensive account of it might be arrived at by utilising the valuable elements from both of them (Oduor 2009, Chapters 4-5).

It is also important to note that there are various forms of teleology, depending on what they say about who is to benefit from the consequences to be produced by the individual's actions. The best known forms of teleology are ethical egoism, altruism and utilitarianism. While ethical egoism seeks to promote the individual actor's own maximum benefit, altruism seeks to promote the welfare of other people without consideration for the individual actor's own. On its part, 
utilitarianism advocates for the maximization of the welfare of the greatest number of people. Ethical egoism hardly seems to be a serious moral theory, since it is difficult to distinguish between egotism (outright selfishness) and egoism (an enlightened, philosophically grounded endeavour to promote one's own maximum benefit. On the other hand, altruism seems to be impracticable on the basis that it demands that the individual ignores his or her interest - a demand which intuitively seems to be contrary to human nature. This leaves us with utilitarianism, which demands that the individual act to maximize the benefit of the greatest number of people, without over-emphasising the individual's interests, but also without ignoring them.

In view of the foregoing observations, our moral justification for non-violent civil disobedience will be based on relevant arguments from both deontological and utilitarian perspectives. Along with our defence of non-violent civil disobedience from a theoretical standpoint, we shall seek to determine the extent to which this form of political action is applicable to the Kenyan context.

Non-violent civil disobedience can be morally justified on at least nine counts.

First, in a violent struggle, the violence of each side goads the other to greater violence. Each side also uses the violence of the other side to justify its own violence. A non-violent struggle, on the other hand, does not encourage the violence of the opponent to the same degree (Shepard 2002). Thus during the post 2007 Kenyan general elections crisis, some violent attacks were said to have been planned specifically to revenge for violence meted out on certain ethnic groups (see CIPEV 2008). Such violence would have been averted if those who felt aggrieved by the announced election results had restricted their expression of dissent to non-violent forms.

Second, violence generally leaves the two sides as long-standing enemies (Shepard 2002). A number of countries have had decades of hostilities due to the violence that they meted out on each other in the past. Examples in this regard include the Koreans and the Japanese, the Chinese and the Japanese, and the Ethiopians and Eritreans. No such negative effects are attributable to non-violent 
resistance. Thus as Shepard (2002) has noted, "Maybe the most amazing thing about Gandhi's non-violent revolution is, not that the British left, but that they left as friends, and that Britain and India became partners in the British Commonwealth." Thus non-violence does not carry the same risk of antagonising potential allies or confirming the antipathy of opponents (Raz 1979, 267). Indeed, Kenyans are now talking of the need for healing and reconciliation for the very reason that the violence that members of various ethnic groups meted out on each other following the disputed 2007 general elections inflicted wounds that may take generations to heal: this would not have been so if the antagonists had confined themselves to non-violent means of expressing their discontent.

Third, even when an armed insurgency is victorious, the final outcome is often disastrous. Thus the Algerian victory against the French and the Kenyan victory against the British together cost over one million lives, with millions more displaced, hundreds of villages destroyed, several cities and much of the countries' infrastructure severely damaged, the economies wrecked and requiring complete overhauling, and the environments devastated (Zunes 1997). Similarly, while the Kenyan economy had been steadily improving since Mwai Kibaki took power in 2002, it plummeted after the post 2007 elections violence, and has not fully recovered to date. No such losses are associated with non-violent civil disobedience.

Fourth, there is an increased realisation that armed resistance tends to push undecided elements of the population towards the government, as any effects of the violence they suffer serves to convince them that the purported "liberators" are actually "terrorists". In sharp contrast to this, government repression against unarmed resistance movements usually creates greater popular sympathy for the regime's opponents. Indeed, attacks against unarmed demonstrators have often provided the spark that has turned periodic protests into full-scale insurrections, as large segments of the population come out in sympathy with the victims of the repression (Zunes 1997). This explains the tendency of many governments when faced with non-violent resistance to emphasise any violent fringes that may emerge (Tinker 1971, 786-787). In Kenya, the government has violently dispersed 
many peaceful demonstrations, culminating in retaliatory action by sections of the crowd, after which the government has claimed that the organisers of the demonstrations were advocates of violent mass action. Indeed, some Kenyan politicians frequently assert that a call to mass action is a call to violent mass action, contrary to the facts.

Fifth, quite frequently, regimes which come to power through violent means soon forget their pledges to uphold personal liberties. Once in power, the revolutionaries have often failed to establish truly democratic political systems capable of supporting social and economic development. Often disagreements, which could have been resolved peaceably in a non-militarised institution, erupt into bloody factional fighting. Thus some countries, such as Algeria and GuineaBissau, have experienced military coups not long after armed revolutionary movements have ousted colonialists. Others, such as Angola and Mozambique, have had to endure long and costly civil wars which broke out soon after the wars of liberation (Zunes 1997). In contrast to such instability, India, which achieved independence through largely non-violent means, has not had a single military coup for the more than half a century that it has governed itself.

However, critics could offer counterexamples such as those of Nigeria and Ghana, both of which got their political independence from Britain through peaceful means, only to sink into a series of coups, some of which were bloody. On the other hand, Kenya, which achieved its political independence partly due to pressure from the Mau Mau Uprising, has not had a single successful military coup (see McGowan 2003). Thus critics can contend, quite plausibly, that while it is the case that nonviolent means may engender a stable political process, it is not always true that it does; and, conversely, while violent means may give rise to an unstable political process, it is not always true that it does. As such, there were probably other factors at play in the examples on both sides (see Johnson et. Al. 1984; Kposowa and Jenkins 1993; Ngoma 2004). Nevertheless, it seems evident that along with those other factors, a culture of violent civil disobedience can contribute to long-term political instability. As such, it seems reasonable to infer that Kenya is more likely to have greater political stability if its citizens cultivate a culture of non-violent civil disobedience rather than a violent one. 
Sixth, throughout history, acts of non-violent civil disobedience have forced a reassessment of moral, social, political and economic parameters. The Boston Tea Party, the suffragette movement, the struggle for Indian immigrant rights in South Africa and the resistance to British rule in India (both led by Gandhi), the US civil rights movement led by Martin Luther King, Jr., Rosa Parks and others, American student sit-ins against the Vietnam War, and the resistance to apartheid in South Africa are all instances where non-violent civil disobedience proved to be an important mechanism for social change (Brownlee 2007; Zunes 1997, 1999). In the Kenyan context, the non-violent campaign of Prof. Wangari Mathai from October 1989 forced the Moi regime to abandon its plans to build a sixty-storey sky-scraper in Nairobi's Uhuru Park. Her protests, the government's response to them and the media coverage of the events all led foreign investors to withdraw from the project in January 1990, barely three months after her protests began, leaving the Moi regime with no option except to abandon it. Similarly, the nonviolent strategy of the Release Political Prisoners lobby, backed by the prisoners' mothers and other women including Prof. Wangari Mathai in the early 1990s, eventually forced the Moi regime to release all political prisoners in 1993.

It is a fact that violent civil disobedience has also had a substantial impact on socio-political progress. For example, revolutions in Russia and France ushered in epoch-changing political arrangements. One could also cite the American Civil War which ended slavery. In the Kenyan context, the Mau Mau Uprising jolted the British into hastening the process of relinquishing political control (see Berman 1991; Kinyatti 2000). Nevertheless, the perception, popularized in Africa by Marxism, that significant change can only come through violent means, is debunked by the many examples of effective change through non-violent means listed above.

Seventh, there is at least one point in favour of non-violent civil disobedience over legal protest. With regard to dissent in general, Mill (1999) notes that sometimes the only way to make a view heard is to allow, or even to invite, society to ridicule and sensationalise it as intemperate and irrational. In similar vain, Russell (1998, 
635) observes that it is typically difficult to make the most salient facts in a dispute known through conventional channels of participation, because the controllers of mainstream media tend to give defenders of unpopular views limited space to make their case. However, given the sensational news value of illegal methods, urges Russell, engaging in civil disobedience often leads to wide dissemination of a position. Admittedly, the success of this strategy depends partly upon the character of the society in which it is employed; but it should not be ruled out as a strategy for communication (Brownlee 2007).

As we pointed out at the outset of this paper, the Kenyan government frequently reminds its citizens to use legal channels to voice their concerns. However, the government has consistently proved to be slow in responding to concerns that are expressed through legal means. On the other hand, the rampant damage of violent action is well known. As such, while both violent and non-violent civil disobedience would attract greater attention than legal protest, a non-violent approach is preferable to a violent one, for the reasons given in the preceding six arguments.

Eighth, as Shepard (2002) correctly observed, even in revolutions that are primarily violent, the successful ones usually include non-violent civilian actions. Yet nearly every time, these actions are curiously downplayed or ignored by most journalists and historians. What is more, as Shepard further noted, there are other cases in which violence would work, but so would non-violent action with much less harm. Indeed, while some Kenyans probably quietly believe that the violence after the disputed 2007 general elections was necessary to bring about the social changes now being witnessed in the country (chiefly the promulgation of the new constitution in August 2010 and the numerous reforms consequent on it), concerted non-violent civil disobedience would have achieved the same results.

Ninth, one of the greatest advantages of non-violent civil disobedience over violent action is that it caters for human finitude and its attendant fallibility. Ross (1998) stated this point as follows:

The violent struggler, if proven to have been mistaken, has left behind a swathe of suffering and destruction for no good end whatsoever. Mistaken 
violence is liable to result in global catastrophe, while mistaken nonviolence is no more than a personal tragedy for those involved in the struggle - tragic enough, but at least accepted freely (Ross 1998).

In the context of the post 2007 Kenyan elections crisis, the crowds in the slums engaged in inter-ethnic violence out of ignorance of the fact that their fellow slum dwellers were not responsible for the mismanagement of the polls. Concerning this Wrong has written:

The approach was brutally simplistic. Many Kikuyu, especially the young, urban poor, had actually voted ODM, regarding Raila, 'the People's President', as far more sympathetic to their needs than the aloof Kibaki. But mobs don't do nuance (sic). Fury needs a precise shape and target if it is to find expression, and ethnicity provided that fulcrum. The attackers claimed they took action because they could not bear the sound of Kikuyu celebrating 'their man's' victory. But their victims said they would have never been so brazen or so foolish, and pleaded with fellow slum-dwellers to remember they were all poor people, suffering together (Wrong 2009, 307).

\section{Answering Objections to Non-violent Civil Disobedience}

Despite an apparently impressive rationale for non-violent civil disobedience, at least six objections have been leveled against it.

First, civil disobedience results in harm, and any harm is undesirable. Raz (1979, 262) identifies two kinds of harm that easily arise out of non-violent civil disobedience:

(1) it can be a divisive force in society.

(2) since it is normally designed to attract public attention, it can lead people to think of resorting to disobedience to achieve whatever changes in law or policy they find justified.

Furthermore, critics assert that non-violent civil disobedience can encourage not only others to engage in similar disobedience, but also a general disrespect for the law, particularly where the law is perceived to be lenient toward certain kinds of offences (Brownlee 2007).

Nevertheless, proponents of non-violent civil disobedience can respond with Pantham (1983, 182-183) that any harm occasioned by non-violent civil 
disobedience can be seen as the sacrifice necessary to effect socio-political transformation, and that an element of sacrifice is involved not only in non-violent resistance, but also in violent resistance against oppression. It is true that a proponent of violent civil disobedience could argue that a violent approach is morally preferable to a non-violent one in cases where it is clear that there is a balance of positive consequences over negative ones. Thus some people may be injured or may even die because of employing violent means, but these sacrifices would be justified if they are necessary to effect socio-political transformation. Yet the balance of advantage over disadvantage in the two extreme forms of resistance (non-violent and violent) must be determined through some other means, and the foregoing nine arguments in favour of a non-violent approach are worth considering in this regard.

Second, it could be argued that civil disobedience is unbearably slow in achieving desired results. Numerous non-violent campaigns must be organised, at great cost to the participants, before public policy is adjusted in favour of the non-violent resisters. In response to this charge, Shepard (2002) has asserted that even violent action takes long to produce desired results:

... we can still rid ourselves of the idea that violence is necessarily quick. If we look at the Chinese Revolution, for instance, we find that Mao TseTung and his Communist forces were engaged in combat over a period of 22 years. Vietnam was embattled for an even longer period: 35 years. These are not swift victories.

.... We can also dispel the notion that non-violent action has to be slow. The non-violent overthrow of Marcos in the Philippines - measured from the assassination of Benigno Aquino - took only three years (Shepard 2002).

Theodore Roszak once commented on the lack of insight on the part of those who charge that non-violent resistance is slow:

People try nonviolence for a week, and when it 'doesn't work', they go back to violence, which hasn't worked for centuries (cited in Shepard 2002).

Third, some critics have questioned the truth of the assertion that non-violent methods of struggle always cause less injury than violent ones. Thus the carefully staged coup which got rid of Kwame Nkrumah was almost certainly both more 
effective and less bloody than a non-violent struggle would have been in the conditions ruling in Ghana at the time (Macfarlane 1968, 45-46). In response to this charge, proponents of non-violent resistance could point out that the example of Nkrumah's ouster has two possible interpretations. On one interpretation, the military coup saved the country months, or even years, of repressive action which would have been occasioned by non-violent civil disobedience. However, on a second interpretation, the coup was actually largely peaceful, thereby confirming the superiority of non-violence over violence. It is even doubtful if a military coup can properly be viewed as an instance of non-violent civil disobedience.

Fourth, some thinkers have charged that there are cases in which non-violence cannot produce the desired results. Threats to fast unto death or of selfincineration would seem to make sense as acts of political disobedience only if there is reason to believe either that the state authorities are capable of being moved by such acts, or that their committal would lead to a great upsurge of public feeling in support of the cause promoted. Neither condition is likely to apply under highly repressive regimes, which are notorious for their moral insensitivity and their ability to hush up and crush all demonstrations of public protest (Macfarlane 1968, 46). The 1986 Tiananmen Square student demonstrations in China, which were ruthlessly crushed by the Communist regime, quickly come to mind. For Kinyatti (2000), non-violent civil disobedience was incapable of achieving freedom for the Kenyan people:

This [the violent response of the British invaders to the Harry Thuku-led non-violent resistance in the 1920s] clearly demonstrated that Kenya was plagued by a merciless foreign regime whose ideological creed was to maintain repression and exploitation by force of arms. It also demonstrated to many that nonviolence as a form of struggle was inapplicable to the social reality of the country then. It taught them the violent nature of imperialism and its agents, and at the same time it heightened their fighting consciousness and their determination to resist further, ... (Kinyatti 2000, 13).

Thus it might seem reasonable to subscribe to the assertion of Macfarlane (1968, 45) that what methods in practice are available for any appropriate immediate purpose will depend largely on factors such as the nature of the society, the 
gravity of the situation, the importance of the time element, and, above all, the way in which the state deals with political dissenters.

However, Macfarlane neglects the fact that non-violent action has been used with some success against highly intolerant regimes. For example, in 1944, military dictators were ousted non-violently in both El Salvador and Guatemala. Furthermore, during World War II, Norway non-violently and successfully resisted Nazi attempts to reorganise its society along fascist lines. Moreover, in 1968, Czechoslovakian civilians non-violently held Soviet armed forces at bay for a full week, and stopped the Soviet leaders from ever subjugating that country to the degree they had intended (see Sharp 1973). Furthermore, the cases in which non-violent action would not work are also often cases in which violence would prove pointless or worse. Indeed, where violent efforts would be easily contained or instantly crushed, non-violent action may be the only realistic choice (Shepard 2002).

Furthermore, reflecting on non-violent civil disobedience in several parts of the world - in Europe during World War II, with the Buddhists in South Vietnam in 1963, with the African-Americans in the southern part of the United States in the 1950s and 1960s, in the efforts of the Release Political Prisoners lobby in Kenya in the 1990s, and in the Egyptian ouster of Hosni Mubarak early in 2011 - it seems clear that non-violent resistance does not depend upon any particular attitude of the opponent or upon the nature of the political system to be effective. Thus Tinker $(1971,787-788)$ seems justified to conclude that the only aid a democratic framework provides in contrast to a totalitarian one is to make the process easier, or at least safer, for the non-violent resister.

Fifth, it seems evident that recognition of the value of positive actions such as Gandhi's non-violent resistance against oppressive laws is reinforced by the feeling that there are times, for example, in Nazi Germany, when disobedience is morally required even of the average person (Hall 1971, 128-129). However, the objector to non-violent civil disobedience can contend that even those who are treated unjustly can have moral reason to comply with the culpable laws - when, for example, non-violent civil disobedience would expose some persons to risks 
they have not agreed to assume (Lyons 1998, 36). Thus children and the very elderly may be harmed by the state in response to the non-violent civil disobedience of zealous young adults in their communities. To this objection the proponent of non-violent civil disobedience can reply that such casualties (sometimes referred to as "collateral damage") are to be found both in instances of violent and non-violent civil disobedience, so that they do not effectively serve to demonstrate the superiority of one over the other.

Sixth, some thinkers have charged that non-violent civil disobedience is merely a manipulative strategy by the Western liberal democratic establishment to maintain the status quo. Bleiker (2002) has stated this objection thus:

While giving the appearance of radical dissent, non-violent civil disobedience is a reformist practice that often strengthens the existing societal order. In being tolerated only as long as the liberal constitutional framework is not disputed, civil disobedience refuses to question the values of its own political foundations. In this sense, civil disobedience has lost most of the meaning that Thoreau's famous essay originally bestowed upon it. This narrowing down of dissent also demonstrates that in a liberal democratic context, granting and withdrawing popular consent only works in a very restricted way. ..., the withdrawal of consent via civil disobedience is limited to a mere challenging of individual laws or policies that may not be compatible with the generally recognised leitmotifs of the existing legal system. Overwhelmingly, the rest of the State apparatus remains unchallenged by this liberal version of withdrawing consent (Bleiker 2002, 38-39).

Nevertheless, whereas that may be the role that non-violent civil disobedience plays in the West, there is evidence that it has the potential to effect radical change in any society. We have already cited the success of civil disobedience in El Salvador, Guatemala, Norway, India and Czechoslovakia.

\section{Conclusion}

The aim of this paper has been to present a moral justification for the use of nonviolent civil disobedience by Kenyan citizens in pursuit of their aspirations. It set out with a brief outline of the history of political disobedience in Kenya, which has been characterized by a seesaw of violent and non-violent action. It then examined the nature of non-violent civil disobedience, outlining the views of four 
of its most influential advocates, namely, Étienne de La Boétie, Henry David Thoreau, Mohandas Karmachand Gandhi and Martin Luther King, Jr. Next, it presented a moral justification for non-violent civil disobedience by advancing nine arguments in its favour, with special reference to the Kenyan context. This was followed by responses to six objections to this form of political disobedience.

From the foregoing reflections, it is evident that while there are many plausible moral arguments for non-violent civil disobedience, there are also a number of formidable moral objections to it. Nevertheless, in the light of the nine arguments in favour of non-violent civil disobedience presented above, in view of the replies offered to the six objections in the foregoing discussion, and in view of the atrocities that Kenyans have unleashed on their fellow citizens in pursuit of political goals over the last half a century, it is high time that they gave serious consideration to a commitment to non-violent civil disobedience. Besides, as the country continues to implement its new constitution promulgated in August 2010, all Kenyans of good will must continue to push for respect for the liberties of citizens, so that they can participate in strikes, demonstrations and rallies without being harassed by the state. This would greatly reduce the need for civil disobedience, non-violent and violent.

\section{References}

Ajulu, Rok. 2002. "Politicised Ethnicity, Competitive Politics and Conflict in Kenya: A Historical Perspective". African Studies, Vol.61 No.2, pp.252268.

Altman, Andrew. 2007. "Civil Rights". Stanford Encyclopedia of Philosophy. http://plato.stanford.edu/entries/civil-rights

Aristotle. 2000. Nicomachean Ethics. Ross, W.D. trans. The Internet Classics Archive. http://classics.mit.edu//Aristotle/nicomachaen. html

--. 2009. Politics. Jowett, Benjamin trans. The Internet Classics Archive. HTTP://CLASSICS.MIT.EDU/ARISTOTLE/POLITICS . HTML 
Atieno-Odhiambo, E.S. 2002. "Hegemonic Enterprises and Instrumentalities of Survival: Ethnicity and Democracy in Kenya". African Studies, Vol.61 No.2, pp.223- 249.

Badejo, Babafemi A. 2006. Raila Odinga: An Enigma in Kenyan Politics. Lagos: Yintab Books.

Berman, Bruce J. 1991. "Nationalism, Ethnicity, and Modernity: The Paradox of Mau Mau". Canadian Journal of African Studies. Vol.25 No.2, pp.181-206.

Bleiker, Roland. 2002. "Rawls and the Limits of Nonviolent Civil Disobedience". Social Alternatives, Vol.21 Issue 2, Autumn2002, pp.37-40.

Brennan, James R. 2008. "Lowering the Sultan's Flag: Sovereignty and Decolonization in Coastal Kenya". Comparative Studies in Society and History, Vol.50 No.4, pp.831861.

http://eprints.soas.ac.uk/7484/1/Sultan's_Flag. pdf

Brownlee, Kimberley. 2007. "Civil Disobedience". Stanford Encyclopedia of Philosophy.

www.science.uva.nl/ seop/entries/civildisobedience

CIPEV (Commission of Inquiry into PostElection Violence). 2008. Report. Nairobi: CIPEV.

Davis, Ronald L.F. n.d. "Creating Jim Crow: InDepth

Essay". www.jimcrowhistory.org/history/creating2.ht $\underline{m}$

Dixon, Norm. 1992. "Campaign for Kenyan political prisoners". Green Left Weekly, Wednesday, $\quad 8^{\text {th }} \quad$ April, 1992. www.greenleft.org.au/node/4052

Fletcher, George P. 2000. Rethinking Criminal Law. Oxford: Oxford University Press.

Gandhi, Mohandas K. 1961. Non-Violent Resistance (Satyagraha). New York: Schocken Books.

--. 2003 (1928). Satyagraha in South Africa. Valji Govindji Desai, Trans. Ahmedabad: Navajivan Publishing House.

Garrow, David J. 1991. "King's Plagiarism: Imitation, Insecurity, and Transformation". The Journal of American History, Vol.78 No.1, June 1991, pp.86-92. www.jstor.org 
Gert, Bernard. 1969. "Justifying Violence". The Journal of Philosophy, Vol.66 No.19, pp.616628. http://www.jstor.org/stable/2024178

Hall, Robert T. 1971. "Legal Toleration of Civil Disobedience”. Ethics, Vol. 81 No. 2, January 1971, pp.128-142.

Hassan, Ahmed Issack. 2002. "Working Document for the Constitution of Kenya Review Commission on the Kadhi's Courts, Chief Kadhi and Kadhis". KECKRC 10. www.commonlii.org/ke/other/KECKRC/2002 /10.html

Hume, David. 1870 [1777]. Essays: Literary, Moral, and Political. London: George Routledge and Sons.

IREC (Independent Review Commission). 2008. "Report on Kenyan 2007 Elections". Nairobi: IREC.

Johnson, Thomas H., Robert O. Slater and Pat McGowan. 1984. "Explaining African Military Coups d'Etat, 1960-1982". The American Political Science Review, Vol.78 No.3, September 1984, pp.622-640. http://www.jstor.org/stable/1961833

Jonyo, Fred. 2002. "Ethnicity in Multi Party Electoral Politics". Chweya, Ludeki ed. 2002. Electoral Politics in Kenya. Nairobi: Claripress, pp86-107.

Kihoro, Wanyiri. 2005. The Price of Freedom: The Story of Political Resistance in Kenya. Nairobi: Mvule Africa Publishers.

King, Jr., Martin Luther. 1963a. The Strength to Love. New York: Harper and Row.

--. 1963b. "Letter from a Birmingham Jail". 16th April, 1963. www.africa.upenn.edu/Articles.../Letter_Birm ingham.html

--. 1964a. Stride Toward Freedom: The Montgomery Story. New York: Harper \& Row.

--. 1964b. Why We Can't Wait. New York: Harper \& Row.

Kinyatti, Maina wa. 2000. Mau Mau: A Revolution Betrayed, Second Edition. London: Vita Books.

KNCHR (Kenya National Commission on Human Rights). 2008. "On the Brink of the Precipice: A Human Rights Account of Kenya's Post-2007 Election Violence”. Final 
report, 15 ${ }^{\text {th }}$ August, 2008. Nairobi: Kenya National Commission on Human Rights.

Kposowa, Augustine J. and J. Craig Jenkins. 1993. "The Structural Sources of Military Coups in Postcolonial Africa, 1957-1984". The American Journal of Sociology, Vol.99 No.1, July 1993, pp.126-163. http://www.jstor.org/stable/2781957

Kumarappa, Bharatan. 1961. "Editor's Note”. In Gandhi 1961, pp.iii-vi.

La Boétie, Étienne de. 2002. The Politics of Obedience: The Discourse of Voluntary Servitude, With an Introduction by Murray N. Rothbard. Kurz, Harry Trans. Auburn: The Mises Institute.

Lonsdale, John. 1989. "The Conquest State, 18951904”. Ochieng', W.R. ed. 1989. A Modern History of Kenya: 1895-1980. London: Evans Brothers Ltd.

--. 1990. "Constructing Mau Mau". Transactions of the Royal Historical Society, Fifth Series, Vol.40, pp.239-260.

Lyons, David. 1998. "Moral Judgment, Historical Reality, and Civil Disobedience". Philosophy and Public Affairs, Vol. 27 No. 1, pp.31-49.

Macfarlane, Leslie J. 1968. "Justifying Political Disobedience". Ethics, Vol.79 No.1, October 1968, pp.24-55.

Machiavelli, NiccolÒ. 1998. The Prince. Bondanella, Peter ed. Bondanella, Peter and Mark Musa trans.s. Oxford: Oxford University Press.

Matheson, Ishbel. 2008. "Kenya six months on: A new beginning or business as usual?" Minority Rights Groups International Briefing Paper.

www.minorityrights.org/download.php?id=52 5

McElroy, Wendy. 2005. "Henry David Thoreau and 'Civil Disobedience"'. www.fff.org/freedom/fd0503e.asp

McGowan, Patrick J. 2003. "African Military coups d'état, 1956-2001: Frequency, Trends and Distribution". The Journal of Modern African Studies, Vol.41 No.3, September 2003, pp.339-370. http://www.jstor.org/stable/3876235

Mill, John Stuart. 1972. "Considerations On Representative Government”. Acton, H.B. ed. 
Utilitarianism, Liberty, Representative Government. London: Everyman's Library.

--. 1999 [1859]. On Liberty. Alexander, Edward ed. Peterborough, Ontario: Broadview Press.

Morris, A. 1999. "A Retrospective on the Civil Rights Movement: Political and Intellectual Landmarks". Annual Review of Sociology, Vol.25, 1999, pp.517-539. http://links.jstor.org/sici?sici=03600572\%281999\%2925\%3C517\%3AAROTCR $\% 3 \mathrm{E} 2.0 . \mathrm{CO} \% 3 \mathrm{~B} 2-5$

Ndegwa, S.N. 1997. "Citizenship and Ethnicity: An Examination of Two Transition Moments in Kenyan Politics". American Political Science Review, Vol.91 No.3, pp.599-616.

Ngoma, Naison. 2004. "Coups and Coup Attempts in Africa: Is there a Missing Link?" African Security Review, Vol.13 No.3. www.iss.co.za/pubs/asr/13No3/ENgoma.htm

Norman, A.E. 1954. "The Crime of Mau Mau". The Australian Quarterly, Vol.26 No.3, September 1954, pp.74-86.

Odinga, Oginga. 1967. Not Yet Uhuru: An Autobiography. London: Heinemann.

Oduor, Reginald M.J. 2009. Introduction to Ethics. Nairobi: Sophia Publications Ltd.

Olumwullah, O.A.L.A. 1990. "Government". Ochieng', William r. Ed. Themes in Kenyan History. Nairobi: East African Educational Publishers Ltd., pp.88-116.

Omolo, Ken. 2002. "Political Ethnicity in the Democratisation Process in Kenya". African Studies, Vol.61 No.2, pp.209-221.

Padmore, George. 1953. "Behind the Mau Mau". Phylon, Vol.14 No.4, pp.355-372. http://www.jstor.org/stable/272073

Pantham, Thomas. 1983. "Thinking with Mahatma Gandhi: Beyond Liberal Democracy". Political Theory, Vol.11 No.2, May 1983, pp.165-188.

Paullin, Theodore. 1944. Introduction to NonViolence. Philadelphia: Pacifist Research Bureau.

Plato. 1945. The Republic. Cornford, Francis MacDonald trans. London: Oxford University Press.

--. 2009a. Apology. Jowett, Benjamin trans. The Internet Classics

Archive. HTTP://CLASSICS.MIT.EDU/PLATO/APOLOGY.HT ML 
--. 2009b. Crito. Jowett, Benjamin trans. The Internet Classics Archive. HTTP:/CLASSICS.MIT.EDU/PLATO/CRITO.HTML

--. 2009c. Laws. Jowett, Benjamin Trans. The Internet Classics Archive. HTTP://CLASSICS.MIT.EDU/PLATO/LAWS.HTML

Rawls, John. 1971. A Theory of Justice. Oxford: Oxford University Press.

Raz, Joseph. 1979. The Authority of Law: Essays on Law and Morality. Oxford: Clarendon Press.

Rosenwald, Lawrence. N.d. "The Theory, Practice \& Influence of Thoreau's 'Civil Disobedience". www.eserver.org/thoreau/theory.html

Ross, Kelley L. 1998. "Violence, Non-Violence, and Progress in History - Satyagraha". www.friesian.com/gandhi.htm

Rothbard, Murray N. 2002. "The Political Thought of Etienne de la Boétie". In La Boétie 2002.

Russell, Bertrand. 1998. Autobiography. London: Routledge.

Sabar-Friedman, Galia. 1995. "The Mau Mau Myth: Kenyan Political Discourse in Search of Democracy". Cahiers d'Études Africaines, Vol.35, Cahier 137, pp.101-131.

Sharp, Gene. 1959. "The Meanings of NonViolence: A Typology". The Journal of Conflict Resolution, Vol. 3, No. 1, March 1959 , pp.41-66. http://links.jstor.org/sici?sici=00220027\%28195903\%293\%3A1\%3C41\%3ATM ONAT\%3E2.0.CO\%3B2-W

--. 1973. The Politics of Nonviolent Action. Boston: Porter Sargent Publisher.

Shepard, Mark. 2002. "Mahatma Gandhi and His Myths: Civil Disobedience, Nonviolence, and Satyagraha in the Real World". www.markshep.com/nonviolence/Myths.html

Suber, Peter. 1999. "Civil Disobedience". Gray, Christopher B. ed. Philosophy of Law: An Encyclopedia. New York: Garland Publishing Co., pp.110-113. www.philwiki.wetpaint.com/page/Civil+Diso bedience

Sylvester, Melvin. 1998. "A tribute to Dr. Martin Luther King, Jr.”. www.liu.edu/cwis/cwp/library/mlking.htm 
Thoreau, Henry David. 1848. "Civil Disobedience". WWW.ESERVER.ORG/THOREAU/CIVIL1.HTML

--. 1859. "A Plea for Captain John Brown". WWW.TRANSCENDENTALISTS.COM/THOREAU_P LEA JOHN BROWN.HTM

Tinker, Jerry M. 1971. "The Political Power of Non-Violent Resistance: The Gandhian Technique". The Western Political Quarterly, Vol.24 No.4, December 1971, pp.775-788. http://links.jstor.org/sici?sici=00434078\%28197112\%2924\%3A4\%3C775\%3AT PPONR\%3E2.0.CO\%3B2-M

Tolstoy, Leo. 1948. The Law of Love and the Law of Violence. New York: Rudolph Field.

Wrong, Michella. 2009. It's Our Turn to Eat. London: Fourth Estate.

Zanden, James W. Vander. 1963. "The NonViolent Resistance Movement Against Segregation". The American Journal of Sociology, Vol.68 No.5, March 1963, pp.544550. http://links.jstor.org/sici?sici=00029602\%28196303\%2968\%3A5\%3C544\%3AT NRMAS\%3E2.0.CO\%3B2-6

Zunes, Stephen. 1997. "Nonviolent Action in African Liberation Struggles". Social Alternatives, Vol.16 Issue 2, pp.23-26.

--. 1999. "The Role of Non-Violent Action in the Downfall of Apartheid". The Journal of Modern African Studies, Vol.37 No.1, March 1999, pp.137-169.

http://links.jstor.org/sici?sici=0022278X\%28199903\%2937\%3A1\%3C137\%3A TRONAI\%3E2.0.CO\%3B2-L 